УдК 621.9

\title{
СУЧАСНИЙ СТАН I АНАЛІЗ ЗАСТОСУВАННЯ ПОВЕРХНЕВОГО ПЛАСТИЧНОГО ДЕФОРМУВАННЯ У ПОЛІГРАФІЧНОМУ МАШИНОБУДУВАННІ
}

๑ С. М. Зигуля, аспірантка, НТУУ “КПІ», Київ, Україна

Проведен анализ методов повышения надежности и долговечности полиграфических машин поверхностным пластическим деформированием. Предложена и разработана классификация статических и ударных методов поверхностного пластического деформирования.

The analysis methods to improve the reliability and durability of printing machines surface plastic deformation was pursued. The classification of static and shock methods of surface plastic deformation were proposed and fully developed.

Постановка проблеми

Підвищення ефективності обробки деталей шляхом застосування нових енерго- і ресурсозберігаючих технологічних процесів, а також методів обробки, які дозволяють підвищити продуктивність з одночасним поліпшенням якості отриманих виробів [1].

Одним з основних показників якості машини є надійність, яка істотно залежить від експлуатаційних властивостей деталей і 3'єднань.

Одним із сучасних напрямків підвищення надійності та довговічності машин є отримання заданих властивостей поверхонь деталей на фінішних операціях, зокрема методами поверхневого зміцнення.

Технологічні можливості методів поверхневого пластичного деформування (ППД) у поєднанні з високою продуктивністю зміцнювальних операцій ставлять його в число найактуальніших і найперспективніших способів зміцнення деталей машин [2].
Підвищення зносостійкості, корозійної, кавітаційно-ерозійної стійкості та забезпечення в матеріалах залишкових напружень стискування в результаті зміцнення ППД робочих поверхонь деталей у поєднанні з дешевизною і простотою реалізації дають підстави для його широкого застосування. Однак, на заваді цьому стоїть неспроможність відомих різновидів способів зміцнення ППД як статичної, так і динамічної дій у забезпеченні значної енергії деформування, здатної підвищити рівень фізикомеханічних характеристик матеріалу поверхневих шарів деталей до рівня вимог експлуатації.

3 огляду на це актуальним залишаються дослідження, спрямовані на вдосконалення відомих і розроблення нових високоефективних способів зміцнення деталей контактуючих пар поліграфічного обладнання, які б забезпечували високий рівень їх експлуатаційних властивостей [3]. 


\section{Аналіз попередніх досліджень}

В умовах експлуатації поверхневий шар деталі піддається суттєвому фізико-механічному впливу: механічному, тепловому, магнітоелектричному, хімічному та ін. Фізико-механічні властивості поверхневого шару змінюються при виготовленні деталей, а потім - в процесі експлуатації під дією силових, температурних та інших факторів. В більшості випадків у деталей погіршуються експлуатаційні властивості поверхні, наприклад, знос, ерозія, кавітація, корозія, втомлювальні тріщини та інші елементи руйнування поверхні розвиваються спочатку в приповерхневому шарі. Тому вимоги, що ставляться до поверхневого шару деталі, більш жорсткі [4].

Існує велика кількість методів та способів розв'язання подібних задач, що ґрунтуються на процесах обробки поверхонь металевих деталей (в тому числі - іх зміцненні), до них входять: фізичні, хімічні, хіміко-термічні, фізико-хімічні, термічні та інші методи [5]. Проте використання кожного із методів чи способів має певні обмеження в умовах поліграфічного виробництва, більш того, їх використання має відбуватися із врахуванням специфіки процесів друкування та післядрукарської обробки поліграфічної продукції. Сьогодні одним з найбільш поширених у поліграфічному машинобудуванні є методи ППД [6-10].

Найбільш розповсюджені методи зміцнення ППД навели у своїй роботі Данько К. А. та І. В. Зорік, де показано, що
- зовнішні циліндричні поверхні можна обробляти обкатуванням роликами/кульками, алмазним вигладжуванням, вібраційною обробкою (ультразвуковим зміцненням, вібраційним абразивним поліруванням, вібраційним галтуванням, вібраційним зміцненням), дробоструминною (пневмодробоструминною, гідродробоструминною), центробіжною динамічною обробкою (обробкою кульками, обробкою щітками, обробкою пружним інструментом), чеканкою, обробкою вибуXOM;

- отвори можна обробляти алмазним вигладжуванням, дорнуванням, розкатуванням (центробіжною обробкою кульками, ротаційним розкатуванням роликами), вібраційною обробкою (віброгалтуванням, вібраційним зміцненням), дробоструминною (пневмодробоструминною, гідродробоструминною), чеканкою, обробкою дробовими пристроями хаотичного типу, пневматичною імпульсною обробкою, обробкою вибухом;

- торці і краї отворів обробляють обкатуванням роликами/кульками, алмазним вигладжуванням, дробоструминною (пневмодробоструминною, гідродробоструминною), чеканкою, обробкою вибухом;

- плоскі поверхні обробляють обкатуванням роликами/кульками, алмазним вигладжуванням, вібраційною обробкою (ультразвуковим зміцненням, вібраційним абразивним поліруванням, вібраційним галтуванням, вібраційним зміцненням), дробоструминною (пневмодробоструминною, гідродро- 
боструминною), чеканкою, обробкою вибухом;

- фасонні поверхні обробляють обкатуванням роликами/кульками, алмазним вигладжуванням, вібраційною обробкою (ультразвуковим зміцненням, вібраційним абразивним поліруванням, вібраційним галтуванням, вібраційним зміцненням), дробоструминною (пневмодробоструминною, гідродробоструминною), чеканкою, обробкою вибухом [11].

\section{Мета роботи}

Метою роботою є проведення аналізу існуючих на сьогоднішній день сучасних методів збільшення ресурсу деталей поліграфічного обладнання і виявлення найбільш ефективного з точки зору технологічних можливостей і експлуатаційних характеристик робочих поверхонь деталей поліграфічного обладнання. На основі проведеного аналізу розробити узагальнену класифікацію методів ППд.

\section{Результати проведених досліджень}

Існує досить велика кількість різних технологічних методів підвищення якості поверхонь деталей, в тому числі і їх зміцнення. На рис. 1 узагальнено класифікацію методів зміцнення металів залежно від зміцнення утворення плівки на поверхні, зміцнення зміною хімічного складу поверхневого шару металу, зміцнення зміною енергетичного запасу поверхневого шару, зміцнення зі зміною структури поверхневих шарів, зміцнення зі зміною шорсткості поверхні, зміцнення структури всього об'єму металу [2].

Зміцнення деталей ППД знайшло застосування для різноманітних поверхонь - як внутрішніх, так і зовнішніх циліндричних, конусних, сферичних, фасонних, зубчатих, плоских. Таким чином запропоновано класифікацію ППД залежно від призначення методу ППД [2].

Зовнішні умови протікання процесів неоднакові: у газовому середовищі; у рідині; у пасті; без використання або з використанням теплоти при нормальному, підвищеному або високому тиску; у низькому, середньому або глибокому вакуумі; у атмосфері водяної, водогазової або іонної пари; у контрольованих атмосферах екзогазу або ендогазу; у електропровідному або діелектричному середовищі; у середовищі з поверхнево-активними або абразивними властивостями; у магнітному, електричному, гравітаційному або термічному полі. Вибір поєднань зовнішніх умов і характеризує специфічні особливості технологічних процесів (рис. 2).

ППД може бути здійснене одним із багатьох різноманітних способів, які умовно діляться на дві групи - статичні і динамічні або ударні. При статичних способах інструмент діє на оброблювану поверхню 3 певним постійним зусиллям. До них відносяться різноманітні способи вигладжування і накатування, а також дорнування.

При динамічних способах зусилля деформування змінюються від нуля чи якогось іншого певного значення до максиму-

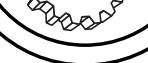

$+$

. (1)

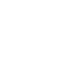



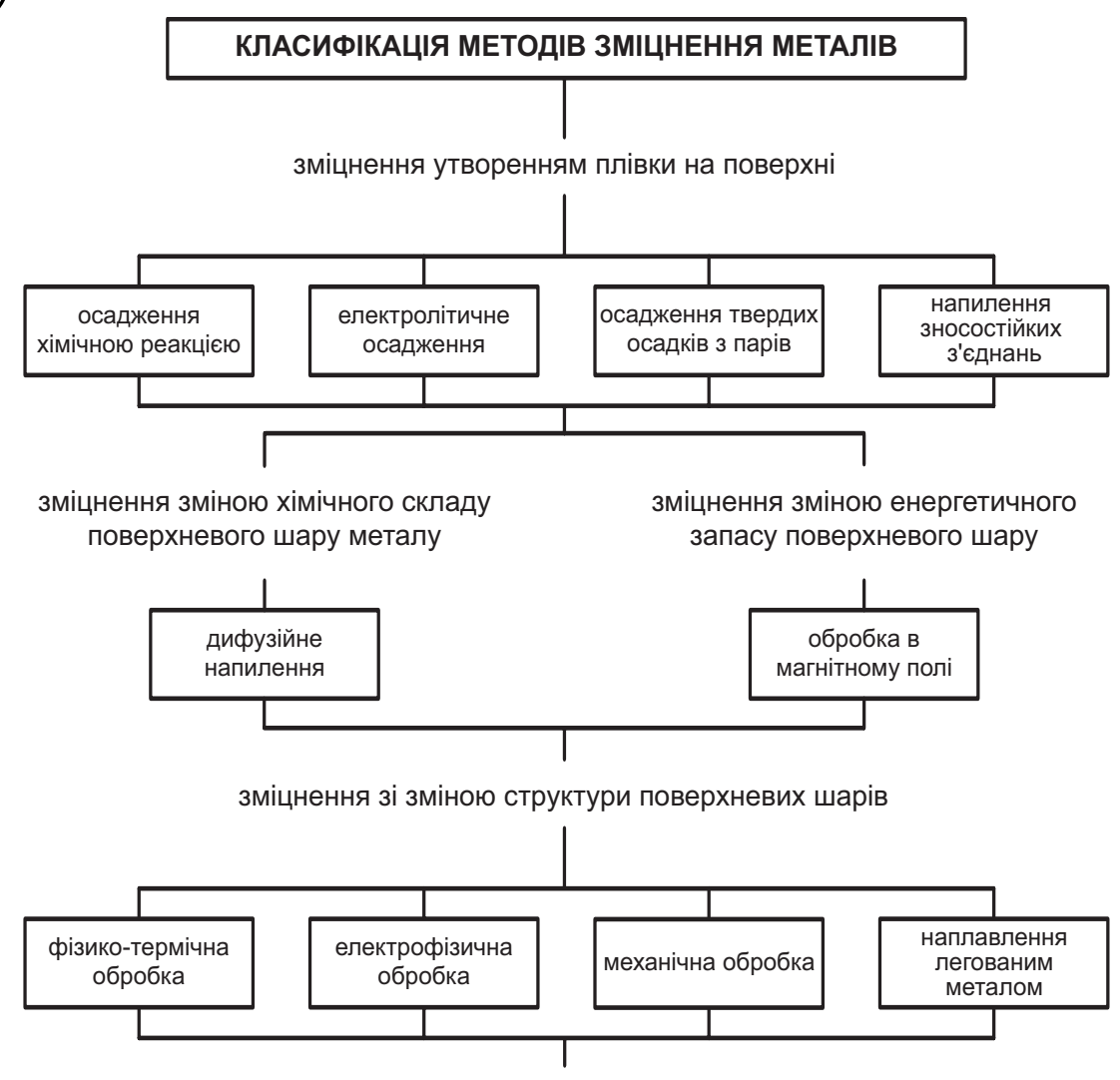

зміцнення зі зміною шорсткості поверхні

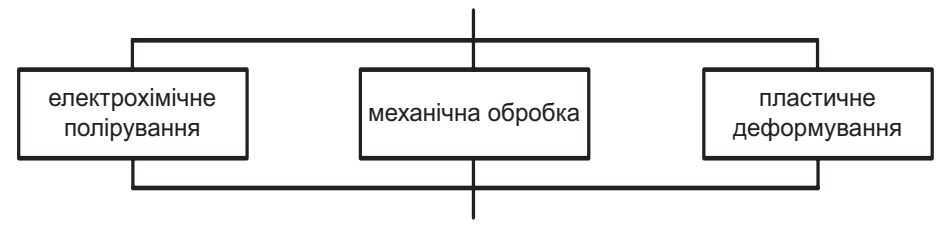

зміцнення структури всього об'єму металу

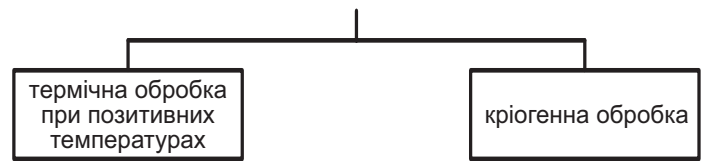

Рис. 1. Класифікація методів зміцнення деталей поліграфічного обладнання

му. При цьому контакт між деталлю і деформувальним елементом може бути постійним чи періодичним.

До динамічних відносяться різноманітні способи чеканки, обробки дробом, вібраційної обробки тощо [12].
Кожен з методів ППД знаходить своє використання в умовах виробництва, але всі вони мають як переваги, так і ряд недоліків. Для обгрунтування доцільності використання певного методу зміцнення для обробки деталей тої чи іншої форми, типорозміру, 


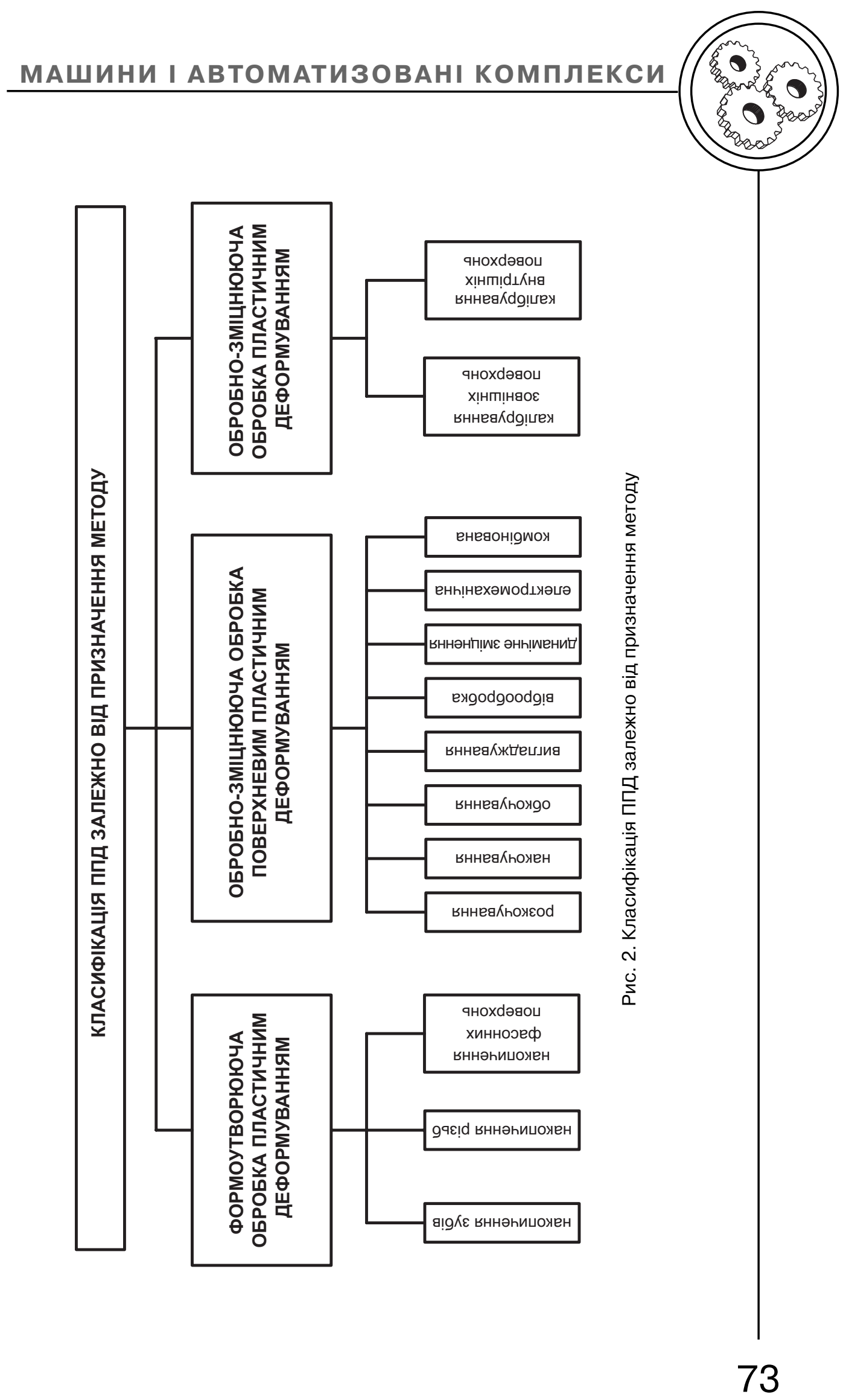


матеріалу проведемо аналіз методів ППД та їх порівняльну характеристику.

Наведемо на рис. 3 класифікацію статичних методів ППД і розглянемо кожний з цих методів.

Зміцнююче розкатування застосовується для обробки поверхонь тіл обертання типу втулок, валів і пласкі поверхні. Цей метод полягає у зминанні виступів мікронерівностей і заповнення впадин за рахунок тиску і переміщень однієї або кількох кульок чи роликів по оброблювальній поверхні [12].

Перевагами методу $є$ те, що не потрібні додаткові витрати енергії (теплової, електричної тощо); обробка здійснюється на звичайному механічному обладнанні і може бути фінішною після механічної обробки (точіння, фрезерування і так дальше) оскільки забезпечує достатньо високу якість поверхні - на рівні шліфування і навіть полірування.

Недоліками цього методу $\epsilon$ розкатування лише в незначній мірі, виправляються похибки попередньої обробки. Тому попередня обробка заготовок повинна бути точною з урахуванням зминання мікронерівностей і зміни остаточного розміру де- талі. Надмірно великий тиск так само, як і велике число проходів інструменту, руйнує поверхню і може призвести до відшарування її окремих ділянок.

Зміцнююче обкатування застосовують для обробки зовнішніх циліндричних поверхонь, торців і країв отворів, пласких і фасонних поверхонь [12].

За допомогою методу обкатування роликом підвищується втомна міцність і довговічність. Можливість отримання поверхні з низькою шорсткістю. Залишкові напруження поширюються на велику глибину. Межа витривалості в корозійному середовищі підвищується більш ніж в 4 рази.

При застосуванні методу обкатування кулькою здійснюється самовстановлення кулі під час обробки, що забезпечує отримання менш шорсткої поверхні при невеликому тиску кулі. Як переваги також можна виділити простоту конструкції і універсальність обкатника, втомна міцність може бути підвищена на 30-60 \%, а глибина наклепу не перевищує 5 мм на м'яких матеріалах.

Недоліком цього методу є те, що абсолютна величина залишкових напружень невелика; об-

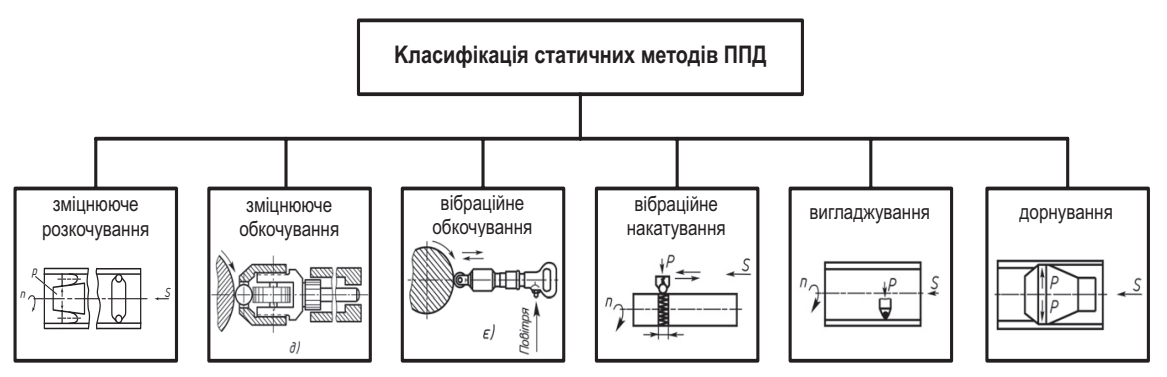

Рис. 3. Класифікація статичних методів ППД 
робка здійснюється при малих подачах (0,06-0,47 мм/об), що збільшить час обробки; якість обробки залежить від властивостей оброблюваного матеріалу, стану вихідної поверхні і режимів обкатування.

Вібраційне обкатування застосовується для обробки зовнішніх циліндричних поверхонь, отворів, пласких і фасонних поверхонь. Цей метод полягає в деформуванні при відносній вібрації інструмента чи робочих тіл і матеріалу, що деформується [12].

Перевагою цього методу є те, що поверхневий шар оброблених деталей добре утримує змащувальний матеріал, за рахунок великої кількості правильно орієнтованих лунок. При застосуванні вібраційного обкатування деталі поліграфічного обладнання мають підвищену зносостійкість і опірність схоплюванню. Спосіб ефективний у разі обробки нежорстких деталей.

Недоліком цього методу $є$ підвищена розтрата енергії на деформацію, часткове знеміцнення матеріалу робочого інструмента, погіршення роботи технологічного обладнання внаслідок вібрації.

Вібраційне накатування застосовується для обробки зовнішніх циліндричних поверхонь, пласких і фасонних поверхонь. Цей метод базується на тонкому пластичному деформуванні поверхневих шарів металу і складному відносному переміщенні оброблювальної деталі і деформуючого інструмента [13].

Перевагами цього методу є:

- незалежне регулювання кроку і висоти нерівностей, що неможливо здійснити при різцевій і абразивній обробці;

- незалежне регулювання напрямку канавок або виступів повністю нового мікрорельєфу;

- утворення мікрорельєфів 3 радіусами заокруглень виступів і заглиблень, на один-два порядки більшими, ніж при відомих способах обробки, з малими кутами нахилу - похилими нерівностями, з малою довжиною ліній профілю;

- кількість виступів і заглиблень нерівностей на одиницю площі можна розраховувати i витримувати 3 великою точністю.

Недоліком цього методу $є$ низька продуктивність при обробці з дискретною поперечною подачею деформуючого елемента по ширині заготовки (за один подвійний хід оброблюється вузька ділянка пласкої поверхні). Труднощі, які виникають в процесі обробки, що пов'язані 3 необхідністю збігу синусоїдальних нерівностей, що утворюються деформувальним інструментом при кожному ході столу верстата.

Вигладжування застосовується для обробки зовнішніх циліндричних поверхонь, отворів, торців і країв отворів, пласких і фасонних поверхонь. Цей метод полягає в пластичному деформуванні оброблювальної поверхні ковзанням по ній інструментом-вигладжувачем [13].

За допомогою зміцнення поверхневого шару металу існують ряд переваг, а саме:

- збільшується твердість, межа пружності і текучості;

- зносостійкість вигладженої поверхні збільшується в 2-3 ра- 
зи порівняно зі шліфованою поверхнею і на 20-40 \% порівняно з полірованою;

- зносостійкість і контактна витривалість вигладженої хромованої поверхні на 35-50 \% вища за поліровану;

- зниження шорсткості поверхні Ra 0,012-0,1 мкм, відсутність переносу на оброблювану поверхню сторонніх частинок;

- можливість обробки тонкостінних деталей і деталей складної конфігурації;

- простота конструкції інструментів вигладжувачів;

- створення високих контактних тисків при невеликих нормальних силах.

Недоліком методу вигладжування $є$ те, що в процесі обробки на поверхні деталі можуть утворюватися напливи, наявність яких знижує експлуатаційні властивості поверхневого шару. Зменшується пластичність металу. Низька продуктивність і невисока стійкість інструменту. Необхідні додаткові операції по попередній обробці поверхні.

Дорнування високопродуктивний процес, що поєднує в собі можливості чистової, зміцнюючої, калібруючої та формотворної обробки. Застосовується для обробки поверхонь типу втулок і труб, використовують переважно для зміцнення внутрішніх циліндричних поверхонь діаметром 10-300 мм. Цей метод полягає в протягування кульки чи дорна через отвір, діаметр якого трохи менше діаметра інструмента [13].

Застосування цього методу дає ряд переваг, а саме:

— підвищує точність отворів;
- забезпечує високу якість поверхні підвищується міцність посадок;

- збільшується довговічність деталей, що мають концентратори напружень у вигляді поперечних отворів;

- поліпшуються фізико-механічні властивості і оброблюваність матеріалу;

- шорсткість обробленої поверхні складає Ra 0,020,13 мкм;

- глибина зміцненого шару досягає 1-3 мкм.

Наведемо на рис. 4 класифікацію ударних методів ППД і розглянемо кожний з цих методів.

Ультразвукова обробка застосовується для таких матеріалів, як агат, алебастр, алмаз, гіпс, германій, граніт, графіт, карбід бору, кварц, кераміка, корунд, кремній, мармур, нефрит, перламутр, рубін, сапфір, скло, тверді сплави, термокорунд, фарфор, фаянс, ферити, кришталь, яшма тощо. Цей метод полягає в тому, що ультразвуковий інструмент під дією статичної і динамічної сил, які створює коливна система (ультразвуковий генератор, магнітострикційний перетворювач і концентратор) пластично деформує приповерхневий шар деталей, попередньо оброблений різанням, здійснюючи одночасне зміцнення та згладжування нерівностей поверхні [2].

За допомогою ультразвукового оброблення досягають підвищення мікротвердості до 180 \%, глибини зміцненого шару до 1,5 мм та підвищення зносостійкості в 1,5-1,8 рази. Знижується сила різання, так як уль- 


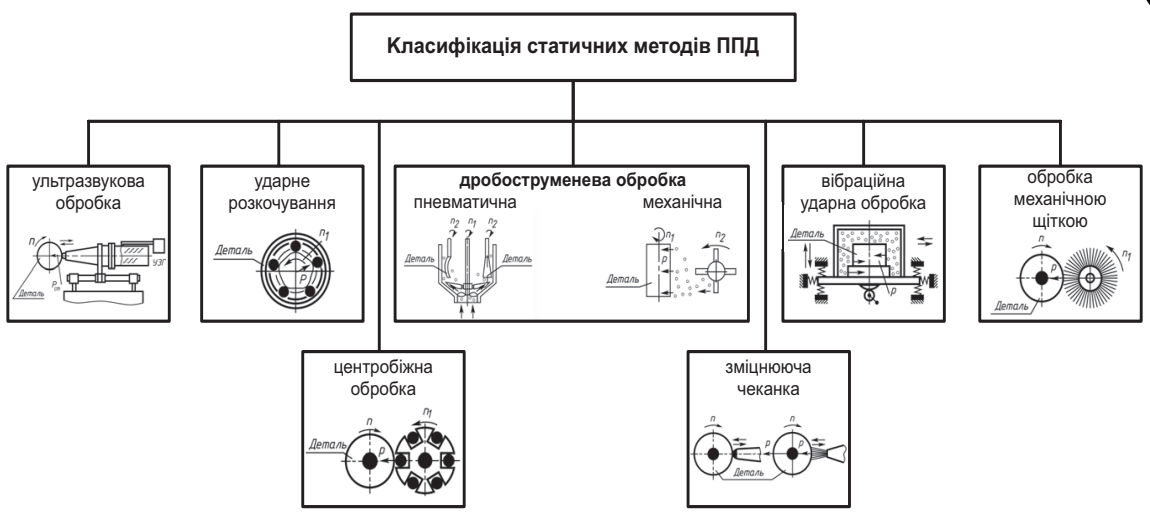

Рис. 4. Класифікація ударних методів ППд

тразвукова обробка здійснюється за невеликими навантаженнями на заготовку, що дозволяє забезпечити високопродуктивність процесу при обробці твердих матеріалів, які чинять опір обробці звичайними способами. Забезпечується висока точність обробленої деталі, зводиться до мінімуму ймовірність відколів країв, тобто 3'являється можливість копіювання складної форми інструменту та фасонної обробки.

Недоліком $є$ те, що тільки крихкі матеріали можна оброблювати цим методом.

Ударне розкатування застосовується для обробки поверхонь типу втулок і труб. Цей метод полягає в ударній взаємодії матеріалу, який деформується 3 інструментом, робочими тілами чи середовищем [12].

Дробоструминна обробка застосовується для обробки поверхонь різної конфігурації, а також для підвищення довговічності таких деталей, як ресорні листи, пружини, лопатки турбін, штоки і штампи. Цей метод полягає в механічному принципі розкидання дробу швидкообертовим потоком 3 вертикальним розміщенням осі його обертання [13].

Перевагами цього методу $є$ висока продуктивність; універсальність, можливість здійснення як загального, так і місцевого зміцнення. При обробці в спеціальних камерах зміцнення великих площ деталі можливо невеликою кількістю дробу (1-2 кг) без іiї заміни. Середнє арифметичне відхилення шорсткості поверхні Ra 0,16-0,63 мкм.

Недоліком $€$ нагрів деформованої поверхні через удари твердих дробинок, які летять 3 великою швидкістю, невисока щільність і рівномірність потоку дробу, що відображається на однорідності й суцільності зміцнення. Погіршення умов праці - пил, частинки окалини, пісок, шум; погіршення шорсткості поверхні. Цей метод вимагає застосування спеціалізованого устаткування. Невелика глибина зміцнення.

Центробіжна обробка застосовується для обробки поверхонь різної конфігурації. Для остаточної обробки поверхні колінчастих валів, поршневих 
кілець, вкладишів підшипників та інших деталей. Цей метод полягає в тому, що на оброблювану поверхню наносять послідовні удари робочими елементами (кулями або роликами), вільно сидячими в радіальних отворах диска, що обертається [13].

Перевагою цього методу $\epsilon$ те, що твердість поверхневого шару підвищується на 20-50 \%, глибина зміцненого шару складає 0,5-3,0 мм, а шорсткість Ra 0,53 мкм.

Недоліком цього методу є те, що необхідна подальша механічна обробка на допустиму глибину до 0,5 мм.

Зміцнююча чеканка застосовується для обробки поверхонь різної конфігурації. Цей метод полягає в упорядкованому ударному впливі на поверхню спеціальними бойками механізованого інструмента пневматичного, електричного або механічного [14].

Перевагою цього методу є те, що після обробки твердість поверхні збільшується на 30-50 \%, глибина зміцнення складає до 30 мм. Чеканка ефективна для обробки деталей машин, таких як зубчасті колеса, шлицеві вали 3 різних матеріалів. Добре зміцнюються чеканкою зварні шви.

Вібраційна ударна обробка застосовується для обробки поверхонь різної конфігурації. Цей метод полягає в вібраційному ударному поверхневому пластичному деформуванні закріплених заготовок в замкнутому просторі [15].

Застосування цього методу призводить до підвищення зносостійкості, опору втомі на 15-70\%, довговічності в 3-10 разів від умов роботи деталей, режимів і технологічного зміцнення матеріалу, вихідного стану поверхні, попередньої термообробки, контактної жорсткості, корозійної стійкості та інших властивостей.

Недоліком $€$ односторонній динамічний вплив на заготовку і елементи верстата, що обмежує можливість його застосування для обробки мало- i нерівножорстких деталей, що призводить до зниження жорсткості верстатів, появи шуму.

Обробка механічною щіткою застосовується для обробки поверхонь різної конфігурації. Цей метод полягає в поверхнево пластичному деформуванні поверхні ударами кінців ворсу механічної щітки, яка обертається [15].

Недоліком $€$ те, що при сильному натиску на поверхні можуть утворитися смуги і штрихи від ударів дроту.

Проаналізувавши методи ППД можна зробити висновок, що цей метод має багато переваг. До основних можна віднести зменшення шорсткості, можливість отримання заданих параметрів величини і глибини зміцнення поверхневого шару, можливість регулювання параметрами мікрорельєфу оброблюваних поверхонь (наприклад, з метою кращого маслоутримування, меншого зношування, корозії тощо). До недоліків методів ППД слід віднести неможливість відновлювання зношених поверхонь деталей, низька продуктивність і швидке зношування обладнання для ППД (робочі частини піско-, дробоструйних апаратів, ролики, алмазні наконечники) [11, 16-29]. 
Самим складним у вирішенні проблеми нормування якості поверхні $€$ нерегулярний, або навіть хаотичний характер мікрорельєфу поверхні, який утворюється у більшості випадках при використанні технологічних процесів існуючих способів обробки. Такий неоднорідний мікрорельєф ускладнює в багатьох випадках керування геометричними характеристиками якості поверхні на основі аналітичних розрахунків таких величин, як фактична поверхня контакту сполучених деталей. Ускладнюється і технологічне забезпечення потрібної шорсткості, так як неоднорідна пластична деформація явно порушує основні геометричні залежності між розмірами мікронерівностей і технологічними факторами. Неоднорідність мікрорельєфу також ускладнює процес контролю геометричних характеристик якості поверхні. Таким чином актуальним $є$ продовження дослідження процесів фінішної обробки, які забезпечують утворення поверхні з регулярним мікрорельєфом.

Однією із задач поліграфічного машинобудування $€$ підвищення контактної жорсткості. Теоретичні дослідження показують, що контактна жорсткість циліндричних з'єднань залежить від номінального діаметру та зазору, які формують номінальну площу контакту.

Контакт деталей виникає по фактичній площі, обумовленій наявністю на поверхнях деталей шорсткості. Контактна площа залежить від дійсної мікрогеометрії й хвилястості контактуючих поверхонь, розташувань по- верхонь і від навантажень, що діють у контакті. Для кожної пари існує цілком визначена оптимальна фактична площа контактування, що $€$ сукупністю плям контакту, розташованих на номінальній площі. Така система плям задається відповідними методами геометричного розрахунку і розрахунку на міцність, що забезпечується технологічним шляхом на операціях механічної обробки.

Ефективним способом підвищення якості поверхневого шару, а також підвищення площі контакту до $100 \%$ є метод вібраційного накатування, який дає можливість підвищити однорідність мікрорельєфу поверхнею деталей і керування мікрорельєфом (регулювання розмірів, форми і взаєморозташування мікронерівностей), що в свою чергу покращує найважливіші експлуатаційні властивості деталей машин.

\section{Висновки}

Проведений огляд і аналіз відомих методів зміцнювальної обробки деталей поліграфічних машин засвідчує, що одним із найактуальнішим і найефективнішим методом зміцнення $€$ метод ППД, а саме вібраційне накатування. Цей метод зменшує шорсткість, дозволяє отримувати потрібні параметри мікрорельєфу, глибину зміцнення поверхневого шару, мікротвердість поверхні. А також завдяки застосуванню вібраційного накатування забезпечуються необхідні параметри мікрорельєфу та якості поверхневих шарів, що сприяє покращенню фізико-механічних і експлуа- 
таційних властивостей, а також геометричних параметрів робочих поверхонь друкарського циліндра та обтяжки.

Розроблено узагальнену класифікацію методів зміцнення металу залежно від зміцнення утворення плівки на поверхні, зміцнення зміною хімічного складу поверхневого шару металу, зміцнення зміною енерге- тичного запасу поверхневого шару, зміцнення зі зміною структури поверхневих шарів, зміцнення зі зміною шорсткості поверхні, зміцнення структури всього об'єму металу.

Розроблено класифікацію методів ППД залежно від призначення методу, а також запропоновано класифікацію статистичних і ударних методів ППД.

1. Б. И. Бутаков. Повышение контактной прочности стальных деталей с помощью поверхностного пластического деформирования / Б. И. Бутаков, Д. Д. Марченко // Проблеми трибології. - 2008 - № 1. - С. 14-23. 2. Дерефінка І. С. Стан і аналіз сучасних методів підвищення надійності деталей машин поверхневим зміцненням / І. С. Дерефінка // Вісн. Нац. ун-ту «Львівська політехніка». Сер. Оптимізація виробничих процесів і технічний контроль у машинобудуванні та приладобудуванні. - 2007. - № 583. C. 18-24. 3. Іоргачов В. Д. Технологічне забезпечення показників зміцнення поверхневого шару деталей машин методом пластичного деформування : дис. ... канд. техн. наук : 05.02 .08 / Іоргачов Вадим Дмитрович. - О., 2008. 179 с. 4. Підвищення надійності деталей і вузлів поліграфічного та металообробного технологічного обладнання [Текст] : Звіт про науково-дослідну роботу / НТУУ«КПІ» ; П. О. Киричок. - Тема №2992-Ф ; КВНТДІ.2-11.02.08 ; 0106U007487. - К., 2007. - 232 с. 5. Лотоцька О. І. Підвищення експлуатаційних властивостей деталей поліграфічних машин / О. І. Лотоцька // Технологія і техніка друкарства. - К. : ВПІ НТУУ «КПІ». - 2008. - № 3-4. С. 16-20. 6. Лотоцька О. І. Комплексна технологія формування мікрорельєфу на поверхнях циліндричних деталей поліграфічних машин : дис. ... канд. техн. наук : 05.05.01 / Лотоцька Оксана Іванівна. - К., 2012. - 179 с. Бібліогр. : С. 143-154. 7. Несхозієвський А. В. Технологічне забезпечення експлуатаційних властивостей поліграфічного обладнання на основі системи контролю виробництва : дис. ... канд. техн. наук : 05.05.01 / Несхозієвський Антон Вікторович. - К., 2011. - 155 с. - Бібліогр. : С. 149-168. 8. Олійник В. Г. Алгоритм керування технологічним процесом оздоблювальнозміцнюючої обробки деталей поліграфічного обладнання / В. Г. Олійник // Технологія і техніка друкарства. - К. : ВПІ НТУУ «КПІ». - 2007. - № 1-2. С. 188-195. 9. Хмілярчук О. І. Технологічне забезпечення якості та експлуатаційних властивостей деталей поліграфічного обладнання оздоблювально-зміцнюючою обробкою : дис. ... канд. техн. наук : 05.05 .01 / Хмілярчук Ольга Іларіонівна. - К., 2009. - 161 с. - Бібліогр. : С. 123-137. 10. Киричок П. О. Технологічне забезпечення працездатності та надійності елементів та вузлів поліграфічних машин / П. О. Киричок // Технологія і техніка друкарства. - К. : ВПІ НТУУ «КПІ». - 2003. - № 1. - С. 71-79. 11. Данько К. А. Анализ состояния проблемы повышения жизненного цикла деталей авиационных двигателей технологическими методами / К. А. Данько, И. В. Зорик // Авиационно-космическая техника и технология. - 2010. - № 4(71). - С. 47-53. 12. Одинцов Л. Г. Упрочнение и отделка деталей поверхностным пластическим деформированием : справочник / Л. Г. Одинцов. - М. : Машиностроение, 1987. - 328 с. 13. Киричок П. О. Зміцнення поверхонь металевих деталей : навч. посіб. / П. О. Киричок, В. Г. Олійник, Т. Ю. Киричок. - К. : Преса України, 2004. - 
240 с. 14. Технология упрочнения машиностроительных материалов : учеб. пособие-справ. / В. Д. Евдокимов, Л. П. Клименко, А. Н. Евдокимова. - К. : Профессионал, 2006. - 352 с. 15. ГОСТ 18296-72. Обработка поверхностным пластическим деформированием. Термины и определения. - Введ. 1972.12.25. - М. : Изд-во стандартов, 1972. - 13 с. 16. Справочник металлиста в пяти томах. - Т. 5 ; под ред. канд. техн. наук А. Н. Малова. - М. : Машгиз, 1960. - 1184 с. 17. Браславский В. М. Технология обкатки крупных деталей роликами / В. М. Браславский. - М. : Машиностроение, 1966. - 160 с. 18. Барац А. И. Поверхностное упрочнение деталей машин обкаткой роликами / А. И. Барац. - Х. : ГНТИ. 1959. - 137 с. 19. Папшев Д. Д. Упрочнение деталей обкаткой шариковий / Д. Д. Папшев. - М. : Машиностроение, 1968. - 132 с. 20. Внутренние напряжения при обкатке роликами / З. Ф. Финкенштейн, У. Прекель // Черные металлы. 1984. - № 14. - С. 13-17. 21. Торбило В. М. Алмазное выглаживание / В. М. Торбило. - М. : Машиностроение, 1972. - 133 с. 22. Хворостухин Л. А. Повышение несущей способности деталей машин поверхностным упрочнением / Л. А. Хворостухин, С. В. Шишкин, А. П. Ковалев, Р. А. Ишмаков. - М. : Машиностроение, 1988. - 144 с. 23. Хворостухин Л. А. Отделочно-упрочняющая обработка алмазным выглаживанием / Л. А. Хворостухин, Н. В. Плешивцев, В. Н. Бибаев // Вестник машиностроения. 1969. - № 8. - C. 48-50. 24. Diamond burnishing / E. H. Hull // Machinery (N. Y.). - 1962. - Vol. 68. - N 5. 25. Яценко В. К. Повышение несущей способности деталей машин алмазным выглаживанием / В. К. Яценко, Г. З. Зайцев, В. Ф. Притченко, Л. И. Иващенко. - М. : Машиностроение, 1985. - 232 с. 26 . Одинцов В. М. Финшиная обработка деталей алмазным выглаживанием и вибровыглаживанием / В. М. Одинцов. - М. : Машиностроение, 1981. - 160 с. 27. Головань А. Я. Алмазное выглаживание и точение / А. Я. Головань, 3. Г. Грановский, В. Н. Машков. - М. : Машиностроение, 1976. - 290 с. 28. Лукьянец В. А. Физические эффекты в машиностроении : справочник / В. А. Лукьянец [и др.] ; под общ. ред. В. А. Лукьянца. - М. : Машиностроение, 1993. - 224 с. 29. Справочник машиностроителя в 3-х томах. - Т. 2. - Предс. ред. совета - акад. Е. А. Чудаков. - Главн. ред. тома Э. А. Сатель. - М. : МАШГИЗ, 1952. - 1080 с.

1. B. I. Butakov. Povyshenie kontaktnoj prochnosti stal'nyh detalej s pomoshh'ju poverhnostnogo plasticheskogo deformirovanija / B. I. Butakov, D. D. Marchenko // Problemy trybolohii. - 2008 - № 1. - S. 14-23. 2. Derefinka I. S. Stan i analiz suchasnykh metodiv pidvyshchennia nadiinosti detalei mashyn poverkhnevym zmitsnenniam / I. S. Derefinka // Visn. Nats. un-tu «Lvivska politekhnika». Ser. Optymizatsiia vyrobnychykh protsesiv i tekhnichnyi kontrol u mashynobuduvanni ta pryladobuduvanni. - 2007. - № 583. S. 18-24. 3. Iorhachov V. D. Tekhnolohichne zabezpechennia pokaznykiv zmitsnennia poverkhnevoho sharu detalei mashyn metodom plastychnoho deformuvannia : dys. ... kand. tekhn. nauk : 05.02.08 / lorhachov Vadym Dmytrovych. O., 2008. - 179 s. 4. Pidvyshchennia nadiinosti detalei i vuzliv polihrafichnoho ta metaloobrobnoho tekhnolohichnoho obladnannia [Tekst] : Zvit pro naukovodoslidnu robotu / NTUU«KPI» ; P. O. Kyrychok. - Tema №2992-F ; KVNTDI.2-11.02.08 ; 0106U007487. - K., 2007. - 232 s. 5. Lototska O. I. Pidvyshchennia ekspluatatsiinykh vlastyvostei detalei polihrafichnykh mashyn / O. I. Lototska // Tekhnolohiia i tekhnika drukarstva. - K. : VPI NTUU «KPI». 2008. - № 3-4. - S. 16-20. 6. Lototska O. I. Kompleksna tekhnolohiia formuvannia mikroreliefu na poverkhniakh tsylindrychnykh detalei polihrafichnykh mashyn : dys. ... kand. tekhn. nauk : 05.05.01 / Lototska Oksana Ivanivna. - K., 2012. - 179 s. - Bibliohr. : S. 143-154. 7. Neskhoziievskyi A. V. Tekhnolohichne zabezpechennia ekspluatatsiinykh vlastyvostei polihrafichnoho obladnannia na osnovi systemy kontroliu vyrobnytstva : dys. ... kand. tekhn. nauk : 05.05 .01 / 
Neskhoziievskyi Anton Viktorovych. - K., 2011. - 155 s. - Bibliohr. : S. 149168. 8. Oliinyk V. H. Alhorytm keruvannia tekhnolohichnym protsesom ozdobliuvalno-zmitsniuiuchoi obrobky detalei polihrafichnoho obladnannia / V. H. Oliinyk // Tekhnolohiia i tekhnika drukarstva. - K. : VPI NTUU «KPI». - 2007. - № 1-2. - S. 188-195. 9. Khmiliarchuk O. I. Tekhnolohichne zabezpechennia yakosti ta ekspluatatsiinykh vlastyvostei detalei polihrafichnoho obladnannia ozdobliuvalnozmitsniuiuchoiu obrobkoiu : dys. ... kand. tekhn. nauk : 05.05.01 / Khmiliarchuk Olha llarionivna. - K., 2009. - 161 s. - Bibliohr. : S. 123-137. 10. Kyrychok P. O. Tekhnolohichne zabezpechennia pratsezdatnosti ta nadiinosti elementiv ta vuzliv polihrafichnykh mashyn / P. O. Kyrychok // Tekhnolohiia i tekhnika drukarstva. K. : VPI NTUU «KPI». - 2003. - № 1. - S. 71-79. 11. Dan'ko K. A. Analiz sostojanija problemy povyshenija zhiznennogo cikla detalej aviacionnyh dvigatelej tehnologicheskimi metodami / K. A. Dan'ko, I. V. Zorik // Aviacionno-kosmicheskaja tehnika i tehnologija. - 2010. - № 4(71). - S. 47-53. 12. Odincov L. G. Uprochnenie i otdelka detalej poverhnostnym plasticheskim deformirovaniem : spravochnik / L. G. Odincov. - M. : Mashinostroenie, 1987. - 328 s. 13. Kyrychok P. O. Zmitsnennia poverkhon metalevykh detalei : navch. posib. / P. O. Kyrychok, V. H. Oliinyk, T. lu. Kyrychok. - K. : Presa Ukrainy, 2004. - 240 s. 14. Tehnologija uprochnenija mashinostroitel'nyh materialov : ucheb. posobie-sprav. / V. D. Evdokimov, L. P. Klimenko, A. N. Evdokimova. - K. : Professional, 2006. 352 s. 15. GOST 18296-72. Obrabotka poverhnostnym plasticheskim deformirovaniem. Terminy i opredelenija. - Vved. 1972.12.25. - M. : Izd-vo standartov, 1972. - 13 s. 16. Spravochnik metallista v pjati tomah. - T. 5 ; pod red. kand. tehn. nauk A. N. Malova. - M. : Mashgiz, 1960. - 1184 s. 17. Braslavskij V. M. Tehnologija obkatki krupnyh detalej rolikami / V. M. Braslavskij. - M. : Mashinostroenie, 1966. - 160 s. 18. Barac A. I. Poverhnostnoe uprochnenie detalej mashin obkatkoj rolikami / A. I. Barac. - X. : GNTI. 1959. - 137 s. 19. Papshev D. D. Uprochnenie detalej obkatkoj sharikovij / D. D. Papshev. - M. : Mashinostroenie, 1968. - 132 s. 20. Vnutrennie naprjazhenija pri obkatke rolikami / Z. F. Finkenshtejn, U. Prekel' // Chernye metally. — 1984. — № 14. S. 13-17. 21. Torbilo V. M. Almaznoe vyglazhivanie / V. M. Torbilo. - M. : Mashinostroenie, 1972. - 133 s. 22. Hvorostuhin L. A. Povyshenie nesushhej sposobnosti detalej mashin poverhnostnym uprochneniem / L. A. Hvorostuhin, S. V. Shishkin, A. P. Kovalev, R. A. Ishmakov. - M. : Mashinostroenie, 1988. 144 s. 23. Hvorostuhin L. A. Otdelochno-uprochnjajushhaja obrabotka almaznym vyglazhivaniem / L. A. Hvorostuhin, N. V. Pleshivcev, V. N. Bibaev // Vestnik mashinostroenija. - 1969. - № 8. - S. 48-50. 24. Diamond burnishing / E. H. Hull // Machinery (N. Y.). - 1962. - Vol. 68. - N 5. 25. Jacenko V. K. Povyshenie nesushhej sposobnosti detalej mashin almaznym vyglazhivaniem / V. K. Jacenko, G. Z. Zajcev, V. F. Pritchenko, L. I. Ivashhenko. - M. : Mashinostroenie, 1985. - 232 s. 26. Odincov V. M. Finshinaja obrabotka detalej almaznym vyglazhivaniem i vibrovyglazhivaniem / V. M. Odincov. - M. : Mashinostroenie, 1981. - 160 s. 27. Golovan' A. Ja. Almaznoe vyglazhivanie i tochenie / A. Ja. Golovan', Z. G. Granovskij, V. N. Mashkov. - M. : Mashinostroenie, 1976. - 290 s. 28. Luk'janec V. A. Fizicheskie jeffekty v mashinostroenii : spravochnik / V. A. Luk'janec [i dr.] ; pod obshh. red. V. A. Luk'janca. - M. : Mashinostroenie, 1993. - 224 s. 29. Spravochnik mashinostroitelja $\vee$ 3-h tomah. - T. 2. - Preds. red. soveta - akad. E. A. Chudakov. - Glavn. red. toma Je. A. Satel'. - M. : MAShGIZ, 1952. $1080 \mathrm{~s}$.

Рецензент - О. І. Лотоцька, к.Т.н., доцент, НТУУ «КПI»

Надійшла до редакції 19.06.13 